\title{
THE EU MEMBER STATES' RIGHT TO ELECTRICITY MIX
}

\author{
by
}

VIKTOR SZABO*

EU Member States' electricity grids are interconnected and therefore, electricity policy in one Member State may influence the functioning of electricity systems in the other states. This article analyzes the impact of an EU Member State's energy policy on the other Member States from the perspective of the right to determinate their electricity mix. The paper argues that the scope of a Member State's right to electricity mix guaranteed by Article 194(2) TFEU ${ }^{1}$ is limited considerably. The right of a Member State to decide on the choice of its energy sources and the general structure of its energy supply in the electricity sector is restricted by the same rights of the other Member States.

\section{KEY WORDS}

Electricity, Internal Market, Right to Energy Mix, State Sovereignty

\section{INTRODUCTION}

On 1 December 2009 the Lisbon Treaty ${ }^{2}$ entered into force. It introduced a specific energy provision. Energy is now recognized explicitly as the European Union's shared competence. Article 194 TFEU lays down specific energy objectives of the Union and determines the boundaries of the EU's measures in this field. The energy sector is of a vital importance for the EU Member States. The Treaty on the functioning of the European

\footnotetext{
szabo.v@gmail.com,Viktor Szabo has graduated from Faculty of Law, Masaryk University, and Institute for Energy and Regulatory Law, Technical University Berlin. I would like to thank to Prof. Dr. Lydia Scholz for her insightful comments and advice. The views expressed in this article are solely those of the author, and do not necessarily reflect the views of any other person.

1 Treaty on the Functioning of the European Union (hereinafter referred to as "TFEU").

2 Treaty of Lisbon amending the Treaty on European Union and the Treaty establishing the European Community (hereinafter referred to as "Lisbon Treaty").
} 
Union therefore states that the EU measures in the energy sector shall not affect a Member State's right to determine the conditions for exploiting its energy resources, its choice between different energy sources and the general structure of its energy supply. The provision ensures Member States' right to decide on their energy mix, while it does not exclude the exercise of specific Union competences in environment. Protection of the Member States' right to their energy mix has attracted considerable interest of legal scholars. ${ }^{3}$ The majority of legal texts deal with this topic in general, with regard to competences of the Union in environmental protection or a Member State's right to determine the conditions for exploiting its energy resources.

This article addresses the issue from the perspective of a Member State's right to choose between different energy sources and the general structure of its energy supply with a focus on electricity. The paper starts with an outline of sovereignty rights of a state over its energy sector. The following chapter summarizes discussions on the interpretation of Article 194 TFEU and its limitations posed by the right of a state to its energy mix. Finally, the author attempts to draw a picture of a Member State's right to decide on its energy mix in the electricity sector.

\section{STATE SOVEREIGNTY OVER ENERGY SECTOR}

International law recognizes a principle according to which within its territory, each nation-state has a complete, supreme, and independent political and legal control over persons, businesses, entities, activities as well as over its natural resources and environment. ${ }^{4}$ This is known as the doctrine of state sovereignty. ${ }^{5}$

\footnotetext{
3 See e.g. Calliess, Ch., Hey, Ch. 2013, 'Multilevel Energy Policy in the EU: Paving the Way for Renewables? European Journal for Environmental \& Planning Law, vol. 10, no. 2; Fouquet, D., Nysten, J. V., Johnston, A., 2012, 'Design and impact of a harmonised policy for renewable electricity in Europe: Potential areas of conflict of a harmonised RES support scheme with European Union Law (BEYOND2020)! Available at:

‘https://ec.europa.eu/energy/intelligent/projects/en/projects/beyond2020` accessed 5 April 2016; Johnston, A., Marel, E. 2013, 'Ad lucem? Interpreting the New EU Energy Provision, and in particular meaning of Article 194(2) TFEU', European Energy and Environmental Law Review, vol. 22, no. 5; Haraldsdóttir, K. 2014, 'The Limits of the EU Competence to Regulate Conditions for Exploitation of Energy Resources: Analysis of Article 194(2) TFEU', European Energy and Environmental Law Review, vol. 23, no. 6.

4 Nanda V. P., Pring, G. R. 2013, International Environmental Law and Policy for the 21st Century, 2nd rev. edn, Martinus Nijhoff Publishers, Leiden, p. 20.

5 See e.g. Schrijver, N. 1997, Sovereignty over Natural Resources: Balancing Rights and Duties, Cambridge University Press, Cambridge; Hobe, S. 2015, 'Evolution of Principle on Permanent Sovereignty over Natural resources in Permanent Sovereignty over Natural Resources, eds. M. Bungenberg, S. Hobe, Springer, place of publication not stated.
} 
Every state has the right to equality in law with every other state. ${ }^{6}$ The most important aspect of doctrine of sovereign equality is that all states are judicially equal, each state enjoys the rights inherent in full sovereignty and each state has the right to freely choose and develop its political, social, economic and cultural systems. A logical consequence of the sovereignty and equality of all states is a state's entitlement to be free from intervention, by other states, in its sovereign sphere of influence, and a concomitant duty to refrain from intervening in that of others. ${ }^{7}$ Every state has the duty to carry out in good faith its obligations arising from international law, and it may not invoke provisions in its constitution or national legal order as an excuse for failure to perform this duty. ${ }^{8}$

\subsection{THE SCOPE OF SOVEREIGN RIGHTS IN ENERGY SECTOR}

An essential aspect of a state's sovereignty is the power to determine its own economic system and to regulate economic activity within its territory. ${ }^{9}$ The core and precondition of this power is the right of a state to rule on all the activities on the use of its energy resources. It is especially the principle of permanent sovereignty over natural resources which stems from the doctrine of sovereignty and sovereign equality of states.

Development of permanent sovereignty over natural resources has its roots in the desire of newly independent states to freely dispose of their own natural resources and the increasing dependence and demand of developed states for overseas natural sources. ${ }^{10}$ It is a part of current customary international law ${ }^{11}$ and should apply in principle to all states. The resolution of the UN General Assembly ${ }^{12}$ stipulates that the principle shall apply to all peoples and nations. ${ }^{13}$ Since the end of the decolonization process, the UN General Assembly resolutions, however, include fewer

6 Declaration on Rights and Duties of States, UN General Assembly Res 375 (IV) (reprinted in UN GAOR 4th Sess 66-67) UN Doc A/1251 (1949), art. 5.

7 Currie, J. H. and others. 2014, International Law: Doctrine, Practice and the Theory, 2nd edn, Irwin Law, Toronto, p. 240.

8 Declaration on Rights and Duties of States, supra note 4, art. 13, 14.

9 Currie, supra note 7, p. 688.

10 See e.g. Schrijver, supra 5, p. 4ff, 36ff or Hobe, supra 5, p. $1 \mathrm{ff}$.

11 Schrijver, supra note 5, p. 3ff, 369ff.

12 General Assembly of the United Nations (hereinafter referred to as "UN General Assembly").

13 Permanent Sovereignty over Natural Resources, UN General Assembly Res 1803 (XVII) (14 December 14 1962) 17 UN - GAOR Supp. No 17 UN Doc. A/5217, p. 15. 
references to peoples and mainly stress the principle as constituting a right of all states. ${ }^{14}$

The range of sources and activities which is covered by the principle shows a gradual extension. According to different wording it can apply to "natural resources," "natural wealth and resources," "all wealth, natural resources and economic activities." There are also other versions specifying the right to land, subsoil or maritime environment. In more recent declarations of the UN General Assembly there has been a tendency to return to the original wording of the principle, namely "natural resources" or "natural wealth and resources". ${ }^{15}$ The latter wording is understood to include not only natural resources, but also production facilities for their processing. ${ }^{16}$

There is no general legal definition of the term "natural resources" in international law. The term can be defined from various perspectives such as from the viewpoint of economists, natural scientists or geologists. The most detailed attempt to define the term has been made by the Argentinian lawyer Cano. He defines natural resources as "physical natural goods, as opposed to those made by man, which are termed cultural resources" ${ }^{17}$ In a broad sense, natural resources include according to Cano sources such as solar, nuclear, wind, geothermal, tidal, thermal (mineral or plant) energy. ${ }^{18}$

There are also problems with a precise meaning of the term "natural wealth" as it is not clear to what extent it differs from physical natural resources. ${ }^{19}$ The term "natural resources" may refer to the natural wealth of the Earth such as land, soil, forests, rivers, oceans, sun, wind and natural sources of energy. Schrijver understands the term "natural wealth" in his study $^{20}$ as those components of nature from which natural resources can be extracted or which can serve as the basis for economic activities. Not all

\footnotetext{
${ }^{14}$ Hofbauer, J. A. 2009, 'The Principle of Permanent Sovereignty over Natural Resources and Its Modern Implications', LL.M. thesis, University of Iceland, p. 9. For more details see Schrijver, supra note 5 p. $7 \mathrm{ff}$.

15 Schrijver, supra note 5, p. $11 \mathrm{ff}$.

16 Reinhard, H. 1980, Rechtsgleichheit und Selbstbestimmung der Völker in wirtschaftlicher Hinsicht - Die Praxis der Vereinten Nationen, Springer, Berlin, p. 36.

17 Cano, G. J. 1975, 'A Legal and Institutional Framework for Natural Resources Management', Available at: <http://www.fao.org/docrep/012/H0422E/H0422E.pdf> accessed 5 April 2016, p. 30.

18 Ibid.

19 Schrijver, supra note 5, p. 16.

${ }^{20}$ Schrijver, supra note 5, p. 19.
} 
natural-resource benefits are extractable (e.g. ecosystems). In his opinion, natural resources can be described as supplies drawn from natural wealth and may be either renewable or non-renewable which can be used to satisfy the needs of human beings and other living species. Both "natural wealth and resources" and "natural resources" are according Schrijver the object of the principle of permanent sovereignty.

The principle of permanent sovereignty encompasses a wide range of rights. One of the basic tenets of the principle is the right of a state to dispose freely of its natural resources and wealth. The arbitration tribunal in the Texaco v Libyan Arab Republic award ${ }^{21}$ held:

"Territorial sovereignty confers upon the State an exclusive competence to organize as it wishes the economic structures of its territory and to introduce therein any reforms which may seem to be desirable to it. It is an essential prerogative of sovereignty for the constitutionality authorized authorities of the State to choose and build freely an economic and social system. International law recognizes that a State has this prerogative just as it has the prerogative to determine freely its political regime and its constitutional institutions."

The principle precludes a state from derogating from the essence of its sovereign rights over natural wealth and resources. States may, however, by an agreement accept a partial limitation of the exercise of their sovereignty. ${ }^{22}$

The right to dispose freely of its natural resources and wealth is a source of many corollary rights of a state. States have a right to freely determine and control prospecting, exploration, development, exploitation and the use and marketing of natural resources. International law also recognizes other rights of states to their natural resources. States may decide on use of their natural resources in order to promote their national development and management of natural resources pursuant to their environmental policy. They also have the right to regulate, expropriate or nationalize foreign investments.

The principle of permanent sovereignty is limited. It results from the doctrine of sovereign equality meaning that sovereignty of a state is bordered by sovereignty of other states. Exercise of the state's right

${ }^{21}$ Texaco v Libyan Arab Republic, reprinted in 17 ILM (1978) 3-37, para. 59, also in 53 ILR, p. 389.

22 Schrijver, supra note 5, p. 264. 
arising from the principle of permanent sovereignty shall also not contravene with its duties under international law, ${ }^{23}$ such as international environmental protection, the duty not to cause or allow harm or the duty to cooperate. The complexity and specifics of state sovereignty in the energy sector of the EU Member States, their rights and duties are analyzed in detail in the following chapter.

\section{THE EU ENERGY COMPETENCE}

International law deems states to be sovereign. It is argued that territorial jurisdiction in relation to economic matters is, however, now largely constrained by the globalization of social and economic relationships, with greater permeability between the traditional domestic and international boundaries. ${ }^{24}$ This can be demonstrated in particular by the Member States of the EU who engaged in far-reaching transfers of sovereign power to the European Union.

Whereas the beginnings of the European integration were tightly connected to the energy sector, ${ }^{25}$ the EEC Treaty did not identify energy as one of the main policy areas. When the EEC Treaty was concluded, the most important energy source was coal. Interests of six founding Member States ${ }^{26}$ were pooled in the Treaty of Paris $^{27}$ and cooperation in the field of nuclear energy was governed by the Euratom Treaty. ${ }^{28}$ In the years following the establishment of the European Economic Community, oil and gas have gained importance. With regards to electricity, technical development at that time did not allow for large-

${ }^{23}$ Pereira, R., Gough, O. 2013, 'Permanent Sovereignty over Natural Resources in the 21st Century: Natural Resource Governance and the Right to Self-determination of Indigenous People under International Law', Melbourne Journal of International Law, volume 14, no. 2, p. 458.

24 Jayasuriya, K. 1999, 'Globalization, Law, and the Transformation of Sovereignty: The Emergence of Global Regulatory Governance' Indiana Journal of Global Legal Studies, volume 6, no. 2, p. 441; see Westaway, J., Simpson, J. 2011, 'The Disintegration of the Concept of Sovereignty and the Energy Sector in the Europe' in Financial Aspects in Energy: A European Perspective, eds. A. Dorsman and others, Springer, Heidelberg, p. 135.

25 There are three treaties from where the European Union's origin can be traced: the Treaty establishing the European Coal and Steel Community (1951), the Treaty establishing the European Economic Community (1957) and the Treaty establishing the European Atomic Energy Community (1957). Only the Treaty establishing the European Economic Community (hereinafter referred to as "EEC Treaty") did not directly concern energy issues.

26 The Inner Six is represented by Belgium, France, Italy, Luxembourg, Netherlands and West Germany.

27 Treaty establishing the European Coal and Steel Community.

28 Treaty establishing the European Atomic Energy Community (hereinafter referred to as "Euratom Treaty"). 
scale electricity transits between state borders. For this reason, it was considered that trade in other sources of energy, such as oil and gas, would be sufficiently covered by rules on the free movements of goods. ${ }^{29}$ Until the Lisbon Treaty, EU energy measures were thus mainly based on the rules on the free movement of goods (Article 114 TFEU) and environmental protection (Article 192 TFEU). ${ }^{30}$

\subsection{THE SCOPE OF ARTICLE 194 TFEU}

Since the Lisbon Treaty, energy competence of the EU is explicitly recognized in Article 194 TFEU. The article lays down four objectives of the Union energy policy. It should aim to: (a) ensure the functioning of the energy market; (b) ensure security of energy supply in the Union; (c) promote energy efficiency and energy saving and the development of new and renewable forms of energy; and (d) promote the interconnection of energy networks. Without prejudice to the application of other provisions of the Treaties, ${ }^{31}$ the EU bodies shall establish the measures necessary to achieve these objectives. They shall exercise their legislative competences in energy in a spirit of solidarity between the Member States and shall be guided by the principles of the establishment and functioning of the internal markets and the need to preserve the environment. ${ }^{32}$ The competence is shared between the Union and Member States, ${ }^{33}$ which allow Member States to legislate to the extent that the Union has not legislated. ${ }^{34}$

29 Department of Energy \& Climate Change. 2014, 'Energy - Review of the Balance of Competences: Legal Annex to the Energy Review', Available at:

$<$ https://www.gov.uk/government/uploads/system/uploads/attachment_data/file/330481/Le gal_Annex_BOC.pdf> accessed 5 April 2016, p. 5.

30 See Simm, M. 2012, 'The interface between Energy, Environment and Competition Rules of the European Union', XXV FIDE Congress, Tallinn, May/June 2012, p. 18.

31 Treaty on European Union and Treaty on the Functioning of the European Union (hereinafter referred to as "Treaties").

32 Calliess, Hey, supra note 3, p. 94.

33 See Article 4(2)(i) TFEU.

34 Chalmers, D., Davies, G., Monti, G. 2010, European Union Law: Cases and Materials, 2nd edn, Cambridge University Press, Cambridge, p. 208. Case law of the Court of Justice of the European Union (hereinafter referred to as "ECJ") suggests that the EU shall develop its energy policy [see ClientEarth. 2010, 'The Impact of the Lisbon Treaty on Climate and Energy Policy - an Environmental Perpsective. Available at:

$<$ http://www.clientearth.org/reports/clientearth-briefing-lisbon-treaty-impact-on-climateand-energy-policy.pdf $>$ accessed 3 August 2015, p. 8.]. 
Article 194 TFEU has raised doubts as to whether it could be interpreted as a step backwards, ${ }^{35}$ recognition of the status quo $^{36}$ or as a sign of a certain development towards extending the powers of the Union in the sphere of energy. ${ }^{37}$ The reference to the establishment and functioning of the internal market may suggest that the aim of the Member States was not to vest the Union with a completely new competence. However, the text limiting the application of the article "without prejudice to the application of the other provisions of the Treaties", raises a question as to what is the relationship of the article to other provisions of the Treaties.

Article 194 TFEU sets a separate Union competence in energy. Hypothesis of the Article 194(1) TFEU saying that the Union can exercise competence in energy without prejudice to the application to the other provisions of the Treaties does not directly imply a relationship of generality and specialty of legal norms. ${ }^{38}$ Such a relationship shall be based on assessment of the relationship of Article 194(1) TFEU with other legal provisions. In relation to Article 114 TFEU, Article 194(1) TFEU can be considered to be a lex specialis. ${ }^{39}$ It is implied by the wording of Article 114 TFEU, which applies "[s]ave where otherwise provided in the Treaties," and by the fact that energy market is a specific object of Article 194(1) TFEU. This opinion is widely shared among legal scholars. ${ }^{40}$ Relationship of Article 194(1) TFEU with other provisions of the Treaties such as EU environmental competence seems to be more complicated. ${ }^{41}$ Complex analysis of this nature is, however, out of the scope of this paper.

35 Hancher, L., Salerno, F. M. 2012, 'Energy Policy after Lisbon' in EU Law after Lisbon, eds. A. Bioni, P. Eeckhout, S. Ripley, Oxford University Press, Oxford, p. 370.

36 Vedder, H. 2010, 'The Treaty of Lisbon and European Environmental Law and Policy', Journal of Environmental Law, vol. 22, no. 2, p. 285 and Simm, supra note 30, p. 22.

37 See e.g. Pielow, J.-Ch., Lewendel, B. J. 2011, 'The EU Energy Policy after the Lisbon Treaty', in Financial Aspects in Energy: A European Perspective, eds. A. Dorsman and others, Springer, Heidelberg, p. 153; Bjørneby, H. 2010, Investing in EU Energy Security. Exploring the Regulatory Approach to tomorrows Electricity Production, Kluwer Law International, Alphen aan den Rijn, p. $145 \mathrm{ff}$.

38 Schulenberg, S. 2009, Die Energiepolitik der Europäischen Union, Eine kompetenzrechtliche Untersuchung unter besonderer Berücksichtigung finaler Kompetenznormen, Nomos, BadenBaden, p. 415.

39 Lex specialis nature for energy was confirmed in ruling C-490/10 European Parliament $v$ Council of the European Union [2012] ECLI: EU: C: 2012: 525.

40 See e.g. Callies, Hey, supra note 3, p. 97ff; Craig, P., Búrca, G. 2011, EU Law: Text, Cases and Materials, 5th edn, Oxford University Press, Oxford, p. 590; Fouquet, Nysten, Johnston, supra note 3, p. 9ff; Johnston, Marel, supra note 3, p. 181; Haraldsdóttir, supra note 3, p. 210.

41 See e.g. Callies, Hey, supra note 3, p. 94ff; Fouquet, Nysten, Johnston, supra note 3, p. 11ff; Sveen, T. 2014, 'The Interaction between Article 192 and 194 TFEU: Renewable Energy Promotion with a Predominant Environmental Purpose', in EU Renewable Energy Law: Legal Challenges and New Perspectives, ed. T. Solvang, University of Oslo, Oslo, pp. 157-182. 


\subsection{LIMITS OF THE EU ENERGY COMPETENCE}

Article 194(2) TFEU stipulates that EU energy legislation shall not affect a Member State's right to determine the conditions for exploiting its energy resources, its choice between different energy sources and the general structure of its energy supply. The competence is, however, limited "without prejudice to Article 192(2)(c)." The complex answer to the effect of the provision on the EU energy competence would require analysis of several questions: the material scope of the listed rights, ${ }^{42}$ the requirement of the effect on these rights, the relationship between Article 194 TFEU and Article 192(2)(c) TFEU with regard to the applicable decision making procedure in the legislative process. ${ }^{43}$ This chapter is focused on the analysis of the Member State's right to decide on its energy mix in the electricity sector. The following text thus solely addresses the preliminary question as to whether a Member State's right to its energy mix is relative or absolute.

The new energy competence of the EU read in conjunction with the second alinea of Article 194(2) TFEU ${ }^{44}$ balances the EU energy competence with a state's sovereignty over energy resources. The provision makes it clear that certain energy issues shall remain within the control of Member States. The wording of the Article 194(2)(2) TFEU, which states that "such measures shall not affect Member State's right," suggests that the protection of the Member States' rights is absolute. This interpretation is supported by the comparison with Article 192(2)(c) TFEU whose wording "significantly affecting" clearly requires certain intensity of the effect on a Member State right to its energy mix. On the other hand, protection of the three Member States' rights is an exception and shall be interpreted narrowly.

The caveat of Article 194(2) TFEU "without prejudice to the application of the other provisions of the Treaties" indicates that it only applies to the extent to which the Member States have not yet transferred competences by other Treaty provisions. ${ }^{45}$ It has been also confirmed by the ECJ that Article 194(2)(2) TFEU applies solely to measures adopted

42 See e.g. Haraldsdóttir, supra note 3, p. 214.

43 See e.g. Fouquet, Nysten, Johnston, supra note 3, p. 10.

${ }^{44}$ Hereinafter referred to as "Article 194(2)(2)."

45 Fouquet, Nysten, Johnston, supra note 3, p. 18. 
in accordance with Article 194 TFEU. $^{46}$ It is questionable whether there is any matter in the field of energy that can be regulated by the EU without having an effect on the Member State's right in the fields of Article 194(2)(2) TFEU. ${ }^{47}$

Rules on the internal electricity market affect the rights listed in Article 194(2)(2) TFEU as well. Rights of the Member States to decide on certain matters are never absolute and the Member States must respect their obligations under the fundamental rules of the Treaties. Even in the field of the three rights Member States are not free to depart from the fundamental principles of the Treaties such as the principle of nondiscrimination and the four freedoms. ${ }^{48}$ In such a situation it is hard to imagine that the Member States would have intended to establish a competence limit that would ex post take away the competence to adopt pre-existing measures and rather prohibit the adoption of any future measures under the Lisbon Treaty by officially creating a new competence. That would be a paradox. ${ }^{49}$ It may be therefore argued that Article 194(2)(2) TFEU does not exclude any impact on the three rights, no matter how small such an impact may be.

\section{THE EU MEMBER STATES' RIGHT TO ELECTRICITY MIX}

Union measures on energy shall not affect a Member State's choice between different energy sources. The right applies to choices of the states in all three sectors where energy sources are consumed: electricity, heating \& cooling and transport. Heating \& cooling is the biggest energy end-use sector in the EU (46\%), followed by electricity (32\%) and transport (22\%). ${ }^{50}$ It is, however, electricity which attracted the major interest in the Member States' policies on the promotion of $\mathrm{RES}^{51}$.

\subsection{PRIMARY AND SECONDARY ENERGY SOURCES}

The electricity sector differs from the heating \& cooling and transport sector by the physical characteristics of electricity. Electricity is a secondary energy

46 Case T-370/11 Republic of Poland v Commission [2013] OJ L 114/34, para. 17.

47 Schulenberg, supra note 38, p. 402.

48 Haraldsdóttir, supra note 3, p. 212.

49 Fouquet, Nysten, Johnston, supra note 3, p. 18.

50 European Commission. 2015, 'Heating and Cooling in the European Energy Transition: Challenges and Facts', Available at: <http://heating-and-cooling-in-europe.eu/HEATING \%20AND\%20COOLING_brochure.pdf> accessed 5 April 2016, p. 2.

51 Renewable energy sources (hereinafter referred to as "RES"). 
source, which is produced in a process of transformation of primary energy resources such as hard coal, nuclear, hydro-energy, wind and solar power. It is used mainly for lighting purposes and as an input for electrical appliances. Electricity is also partially used for the generation of heating \& cooling and in transport sector.

Heating \& cooling and transport are dependent mainly on the use of primary energy sources (e.g. coal, gas, oil). Primary energy sources for production of energy can be used either directly or indirectly. Whereas electricity represents an intermediary product, which is transported to customers for end-use, primary energy resources in heating \& cooling sector and transport are transformed to thermal and mechanical energy directly.

The characteristics of energy transformation in the three sectors affect the geographic scope of state powers over energy production from primary energy sources. Electricity grids enable transportation of electricity produced in one Member State for final consumption in the other ones. Contrary to that, the physical characteristics of thermal energy allow only for its local use and cross-border trade for heat supply is considerably limited. Mechanical energy transformed from primary energy sources in transport vehicles must be used in the same vehicle where it has been produced. It implies that electricity is the only good transformed from primary energy sources, which can be traded in large amounts across state borders. $^{52}$

\subsection{TERRITORIAL JURISDICTION IN THE ELECTRICITY SECTOR}

In the post-war period EU Member States were restructuring their energy industry. Technical development in the sector did not permit large-scale electricity trade across borders. Energy needs were served by vertically integrated energy monopolies encompassing generation, transmission, distribution and supply of electricity to their customers. At that time Member States had direct control over the energy incumbents and the state was directly responsible to the public for failings in the electricity industry. ${ }^{53}$ Member States exercised control over their electricity sector

52 It is true that the internal market in the EU comprises of trade with electricity, gas, coal as well as other primary energy sources. This article, however, distinguishes between primary energy sources (gas, coal) and electricity as a secondary energy source.

53 Talus, K. 2013, EU Energy Law and Policy: A Critical Account, Oxford University Press, Oxford, p. 271. 
mainly through public ownership and inter-state electricity trade was of minor importance. In such a state of the electricity sector, EU rules on the internal market did not seem to pose any risk to the States with regard to their choice between energy sources for electricity generation.

The old energy economy was, however, watered down by the Commission's ${ }^{54}$ policy aimed at the introduction of an internal market to the electricity and also the gas sector. Vertical hierarchical relations were replaced by commercial relations between market participants. In the ideal form, the functions of generation, transmission, distribution and supply of electricity should be provided by different undertakings. Competition in the generation and supply chain was introduced. Providers of network services were made legally obliged to connect third party generators and suppliers and provide them with transmission and distribution services.

Similar developments can be seen in the electricity trade between Member States. In the old energy economy, electricity interconnections between Member States were used mainly for cooperation between transmission system operators to maintain their transmission grids stable and then later, to import electricity to energy-deficit countries. Cross-border electricity supply contracts were used only by energy incumbents from an import and export country. These long-term contracts from the non-market era limited interconnection capacity for trade between new market players and needed to be terminated. In a newly liberalized economy, access to interconnectors should be non-discriminatory and all transmission capacity should be based on market solutions.

Despite the EU's efforts, interconnection capacity between several countries remains fairly low and insufficient for expected power flows. ${ }^{55}$ However, although the internal market is still far from being complete, in some regions there are already highly meshed networks where interconnection levels between some countries are sufficient ${ }^{56}$ for intensive

54 European Commission (hereinafter referred to as "Commission").

55 European Commission. 2015, 'Communication from the Commission to the European Parliament, the Council, the European Economic and Social Committee and the Committee of the Regions: Launching the Public Consultation Process on a New Energy Market Design', COM (2015) 340 final, p. 10.

56 European Commission. 2015, 'Energy Union Package, Communication from the Commission to the European Parliament and the Council, Achieving the $10 \%$ electricity interconnection target Making Europe's Electricity Grid fit for 2020', COM (2015) 82 final, p. 5 . 
transboundary electricity trade. In situations when electricity production in one Member State is less expensive than in the other one, interconnectors, comprehensive methods of capacity allocation and congestion management enable effective competition between generators located in different countries.

Technical development in the electricity industry together with the Union's efforts to create an internal electricity market have resulted in a situation where it is difficult for a Member State to prefer electricity produced from some energy sources over others. The decision on which primary energy sources shall be used for electricity production and consumption in a particular Member State has been to a large extent moved beyond state borders. The decision now depends more on market forces in the internal market than on Member States. Electricity price depends on the market and it determines investor preference of particular energy sources for electricity production. This raises two questions: (i) who must not interfere with the Member State's right to its electricity mix and (ii) what is the material scope of the right of a Member State to choose between different energy sources protected by Article 194(2)(2) TFEU.

\subsection{WHO IS THE ADDRESSE OF THE OBLIGATION NOT TO INTERFERE WITH THE RIGHT OF A MEMBER STATE TO ITS ELECTRICITY MIX?}

Article 194(2)(2) TFEU guarantees the right of Member States to their electricity mix towards the Union. Any measures of a Union body enacted under Article 194 TFEU shall not affect the Member States' right. The caveat of Article 194(2)(2) protects the right of every EU Member State.

The nature of interconnected electricity systems of Member States' and the aims of the internal market, however, suggest that exercise of the right by one Member State can potentially affect the right of the other one. ${ }^{57}$ This is of importance from the perspective that an action taken by one Member state can affect: (a) operation of interconnected electricity grids and (b) by way of a market mechanism it can influence electricity prices, which in turn determine decisions of investors on energy sources for electricity production.

57 See European Commission. 2010, 'Communication from the Commission to the European Parliament, the Council, the European Economic and Social Committee and the Committee of the Regions: Energy 2020, A strategy for competitive, sustainable and secure energy', $\operatorname{COM}(2010) 639$ final, p. 4. 
This phenomenon can be demonstrated by the decision of Germany to revolutionize its electricity $\mathrm{mix}$ and the increase of RES electricity production in Germany. First of all, increased flows of electricity from Germany to its neighboring countries may affect operation of their transmission grids. Second, large amounts of electricity from RES lower the overall electricity prices on the markets. Although electricity production from RES is still not in large amounts competitive with conventional electricity generation, the production is promoted e.g. via various financial schemes. Whereas the RES generation is supported by German electricity customers, renewable electricity can be sold to customers elsewhere in Europe. This may cause that other electricity generators produce electricity in an economically inefficient way. This raises a question whether the obligation of the Union not to affect Member States' right to their electricity mix entails also a duty to act actively in order to protect the right of one Member State against an action taken by another.

It shall be recalled that the caveat of Article 194(2)(2) TFEU is a limit of the EU energy competence. It is a well-known rule that the EU legal authority is governed by the principle of conferred powers. Under this principle the Union shall act only within the limits of the competences conferred upon it by Member States in the Treaties in order to attain the objectives set out therein. ${ }^{58}$ Article 194(2)(2) TFEU does not constitute a separate EU competence in order to protect the right of a Member State to its electricity mix. It is also dubious whether the EU has such an objective. It should be therefore concluded that whereas the Union may not affect by its measure the right of a Member State to its electricity mix, it is not empowered to take a protective action for the benefit of the right of one Member State against the action taken by the other one.

\subsection{MATERIAL SCOPE OF THE RIGHT TO ELECTRICITY MIX ACCORDING TO ARTICLE 194(2) TFEU}

The EU institutions could probably not adopt a measure directing a Member State to produce electricity from its own energy resources for the benefit of the Union, even in the interests of security of energy supply and/or solidarity through the Union. Nor could the Union

\footnotetext{
58 See Article 5 Treaty on European Union.
} 
institutions usurp the functions of national government in the event of an energy crisis. ${ }^{59}$

It can be recalled that the ECJ decided that the caveat of Article 194(2)(2) TFEU applies only to EU measures adopted under its energy competence. On the other hand, it seems that Member States' governments understand the provisions as a general excuse for preferences of their national energy wishes or targets. ${ }^{60}$ These attitudes may have their roots in the understanding of a sovereign right of a state to economic development and the principle of permanent sovereignty over natural resources. In the process of European integration, the Member States have, however, transferred some aspects of their sovereign power to the Union. The caveat of Article 194(2) TFEU "without prejudice to the application of the other provisions of the Treaties" indicates that the EU energy competence limit applies only to the extent to which the Member States have not yet transferred competences by other Treaty provisions. The competence must be also exercised in the context of the establishment and functioning of the internal market. The limit to the energy competence expressed in the second alinea of the Article cannot be thus interpreted as a restriction to the fundamental principles of the Treaties.

Secondary EU law enables Member States to: (i) direct that priority shall be to a certain extent given to a dispatch of generating installations using indigenous primary energy fuels, ${ }^{61}$ and (ii) choose their RES promotion schemes and the renewable sources which they prefer. ${ }^{62}$ In comparison to other energy sources, electricity production from indigenous fuels

59 See Hancher, Salerno, supra note 35, p. 372; Declaration No 22 annexed to the Final Act to the Constitutional Treaty.

${ }^{60}$ The author of this paper noticed that the right of Member States to their energy mix has been used to justify plans to construct new nuclear power plants in the Prime Ministers of the countries. In response to a question whether the projects are economically viable and whether there would be a need to provide state aids, the prime ministers argue that it is for a Member State do decide which energy sources the states use for their electricity supply. With respect to the opinion of the Slovak Prime Minister see e.g. ceskatelevize.cz. 2015, 'Rakousko hrozí žalobou, pokud dostane české jádro státní podporu', Available at: $<$ http://www.ceskatelevize.cz/ct24/ekonomika/1531552-rakousko-hrozi-zalobou-pokuddostane-ceske-jadro-statni-podporu> accessed 5 April 2016. The president of the Slovak NRA also expressed his opinion that energy prices for final customers in Member States will remain diverse because of differences in energy mix of EU Member States [see energia.sk. 2015, 'Regulátori z V4 podporujú predaj elektriny z OZE za trhové ceny', Available at: <http://energia.dennikn.sk/dolezite/elektrina-a-elektromobilita/regulatori-z-v4podporuju-predaj-elektriny-z-oze-za-trhove-ceny/17176/> accessed 5 April 2016].

61 See Article 15(4) Directive 2009/72/EC of the European Parliament and of the Council of 13 July 2009 concerning common rules for the internal market in electricity and repealing Directive 2003/54/EC [2009] OJ L 211/55. 
and RES is not completely market-based, but it aims at protection of other values such as security of supply or environment.

The right protected under Article 194(2)(2) TFEU can be partly defined in a negative way. Whereas the effective execution of the right of a Member State to choose between different electricity sources is limited, the provision can be seen as to ensure states' control of permits, ${ }^{63}$ licensing and siting of energy sources on their territories. This, however, does not exclude Member States' obligation under the other Treaty provisions such as the principle of non-discrimination and the four freedoms. This interpretation is interlinked with a Member State's right to determine the conditions for exploiting its energy resources and they partially overlap. It does not, however, enable a Member State to directly affect the structure of its electricity supply. ${ }^{64}$

Interpretation of the scope of a Member State's right to choose between different energy sources with an impact on the structure of its electricity supply suggests that the appeal of the Member States to their right to their own electricity mix may be influenced by different policy objectives. The changing conditions in the energy sector result in a situation when energy sources, which used to be a backbone of national economies, become economically inefficient. This may imply an increase of the unemployment rate. ${ }^{65}$ Electricity supply also remains highly politicized and the public still expects the state to be the controller of the last resort. ${ }^{66}$ The author of this article thus suggests that the Member States' appeals to their right

62 See Article 3 Directive 2009/28/EC of the European Parliament and of the Council of 23 April 2009 on the promotion of the use of energy from renewable sources and amending and subsequently repealing Directives 2001/77/EC and 2003/30/EC [2009] OJ L 140/16. See case C-573/12 Alands Vindkraft AB v Energimyndigheten [2014] OJ C292/4, paras. 57-63.

63 See Declaration No 35 on Article 194 TFEU. With regard to nuclear energy see e.g. Joint Declaration on the Application of the Euratom Treaty (No 4) adopted by the plenipotentiaries of the Treaty concerning the accession of the Kingdom of Norway, the Republic of Austria, the Republic of Finland and the Kingdom of Sweden to the European Union OJ C 241, 29/08/1994, p. 382.

64 See Gräper, F., Schoser, Ch. 2010, 'Third Party Access', in EU Energy Law: The Internal Market, Third Liberalisation Package, 3rd edn, ed. Ch. Jones, Clayes \& Casteels, place of publication not stated, p. $540 \mathrm{ff}$.

65 While it is argued that a higher deployment of RES creates more jobs, some governments hesitate and consider whether the termination of some traditional economic activities such as coal mining would result in an increase of the overall unemployment rate. With regard to structural unemployment see e.g. McEachern, W. A. 2006, Economics: A Contemporary Introduction, 7th edn, Thomson South-Western, Mason, p. 497 or Gwartney, J. D., Stroup, R., Studenmund, A. H. 1980, Macroeconomics: Private and Public Choice, 2nd edn, Academic Press, London, p. 145ff.

${ }^{66}$ Talus, supra note 53, p. $272 \mathrm{ff}$. 
to electricity mix may be used as a veil encompassing other objectives, whose relations to the core of the right may be weak.

\section{CONCLUSIONS}

This paper analyzed the content and the extent of sovereign rights of states in energy from the perspective of international law with specific regard to European integration and the scope of the protection provided to Member States by Article 194(2)(2) TFEU with a focus on electricity. Under international law, states enjoy sovereign power to decide on all aspects of their energy policy. Their powers are, however, not unlimited and shall respect the same rights of other states and their obligations arising from international law.

In the process of the European integration states transferred exercise of some of these rights to the Union. Energy policies of the Member States and actions of the EU must comply with fundamental principles of the Treaties such as the principle of non-discrimination and the four freedoms. With regard to the right of a Member State to decide on its choice between different energy sources and the general structure of its energy supply, application of rules on the free movement of goods sets important limits and in particular to those rights in the electricity sector.

In the transportation and heating \& cooling sectors, the physical characteristics of secondary energy sources enable the states to decide on their choice between different energy sources and the structure of its energy supply effectively. The same does not apply to the electricity sector. Meshed electricity networks and the development of the internal market do not respect national borders and diminish state's right to choose between different energy sources and the structure of its electricity supply. The price of electricity is determined according to market principles and it affects preferences of investors to particular energy resources for electricity production. Member States, however, even after the introduction of Article 194 TFEU still retain important competences in energy. They can control permitting of new electricity generation facilities and the licencing and siting of production units on their territories. No measure of a Union institution under Article 194 TFEU can significantly affect these rights.

Comparison of the scope of the Member States' rights shows that the Member State's right to its own electricity mix is exercised by different actors simultaneously. Whereas the competence to decide on permits, 
licences and siting of energy facilities remain in a Member State's hands, actual control over the origin of electricity supplied in the national territory has been transferred beyond state borders.

In the internal market, electricity prices should be driven mainly by market forces. Member States can, however, still prioritize their indigenous primary energy sources and promote RES according to their national energy policies. Exercise of these rights together with the prerogatives of Member States protected by Article 194(2)(2) TFEU to a large extent influences from which sources electricity is to be produced. It can be therefore concluded that this part of a Member State's right to its own energy mix is influenced by joint execution of the same right by all other Member States. The EU comprises, however, of countries with significant disparities with regard to their size, economic situation and opinion on prospective energy policy. It implies that Member States with large market leverage can de facto impose their energy policy on other ones.

\section{LIST OF REFERENCES}

Andoura, S., Hancher, L., Woude, M. 2010, 'Policy Proposal' by Jacques

Delors, Towards a European Energy Community: A Policy Proposal', Available at:

$<$ http://www.institutdelors.eu/media/europeanenergycommunity-

andoura-hancher-vanderwoude-ne-march10.pdf?pdf=ok> accessed 5 April 2016

Calliess, Ch., Hey, Ch. 2013, 'Multilevel Energy Policy in the EU: Paving the Way for Renewables?', European Journal for Environmental \& Planning Law, vol. 10, no. 2

Cano, G. J. 1983, 'Legislative Study No. 9. A Legal and Institutional Framework for Natural Resources Management', Available at: $<$ http://www.fao.org/docrep/012/H0422E/H0422E.pdf > accessed 5 April 2016 
ceskatelevize.cz. 2015, 'Rakousko hrozí žalobou, pokud dostane české jádro státní podporu', Available at:

<http://www.ceskatelevize.cz/ct24/ekonomika/1531552-rakousko-hrozizalobou-pokud-dostane-ceske-jadro-statni-podporu> accessed 5 April 2016

Chalmers, D., Davies, G., Monti, G. 2010, European Union Law: Cases and Materials, $2^{\text {nd }}$ edn, Cambridge University Press, Cambridge

ClientEarth. 2010, 'The Impact of the Lisbon Treaty on Climate and Energy Policy - an Environmental Perspective'. Available at:

$<$ http://www.clientearth.org/reports/clientearth-briefing-lisbon-treatyimpact-on-climate-and-energy-policy.pdf> accessed 5 April 2016

Currie, J. H. and others. 2014, International Law: Doctrine, Practice and the Theory, $2^{\text {nd }}$ edn, Irwin Law, Toronto

Czeberkus, M. A. 2013, 'Renewable Energy Sources: EU Policy and Law in Light of Integration', LL.M. thesis, University of Iceland

Declaration on Rights and Duties of States, UN General Assembly Res 375 (IV) (reprinted in UN GAOR $4^{\text {th }}$ Sess 66-67) UN Doc A/1251 (1949)

Department of Energy \& Climate Change. 2014, 'Energy - Review of the Balance of Competences: Legal Annex to the Energy Review' Available at:

<https://www.gov.uk/government/uploads/system/uploads/attachment_ data/file/330481/Legal_Annex_BOC.pdf> accessed 5 April 2016, p. 5

Directive 2009/28/EC of the European Parliament and of the Council of 23 April 2009 on the promotion of the use of energy from renewable sources and amending and subsequently repealing Directives 2001/77/EC and 2003/30/EC [2009] OJ L 140/16 
Directive 2009/72/EC of the European Parliament and of the Council of 13 July 2009 concerning common rules for the internal market in electricity and repealing Directive 2003/54/EC [2009] OJ L 211/55

energia.sk. 2015, 'Regulátori z V4 podporujú predaj elektriny z OZE za trhové ceny', Available at: <http://energia.dennikn.sk/dolezite/elektrinaa-elektromobilita/regulatori-z-v4-podporuju-predaj-elektriny-z-oze-zatrhove-ceny/17176/> accessed 5 April 2016

European Commission. 2010, 'Communication from the Commission to the European Parliament, the Council, the European Economic and Social Committee and the Committee of the Regions: Energy 2020, A strategy for competitive, sustainable and secure energy COM (2010) 639 final

European Commission. 2015, 'Energy Union Package, Communication from the Commission to the European Parliament and the Council, Achieving the $10 \%$ electricity interconnection target Making Europe's Electricity Grid fit for 2020', COM (2015) 82 final

European Commission. 2015, 'Heating and Cooling in the European Energy Transition: Challenges and Facts', Available at:

<http://www.klimats2015.lv/files/files/HEATING\%20AND \%20COOLING_brochure.pdf> accessed 5 April 2016

Evans, M. D. 2014, International Law, $4^{\text {th }}$ edn, Oxford University Press, Oxford

Fouquet, D., Nysten, J. V., Johnston, A., 2012, 'Design and impact of a harmonised policy for renewable electricity in Europe: Potential areas of conflict of a harmonised RES support scheme with European Union Law (BEYOND2020)' Available at: 
https://ec.europa.eu/energy/intelligent/projects/en/projects/beyond2020 accessed 5 April 2016

Gräper, F., Schoser, Ch. 2010, 'Third Party Access' in EU Energy Law: The Internal Market, Third Liberalisation Package, $3^{\text {rd }}$ edn, ed. Ch. Jones, Clayes \& Casteels, place of publication not stated

Gwartney, J. D., Stroup, R., Studenmund, A. H. 1980, Macroeconomics: Private and Public Choice, $2^{\text {nd }}$ edn, Academic Press, London

Hancher, L., Salerno, F. M. 2012, 'Energy Policy after Lisbon' in EU Law after Lisbon, eds. A. Bioni, P. Eeckhout, S. Ripley, Oxford University Press, Oxford

Haraldsdóttir, K. 2014, 'The Limits of the EU Competence to Regulate Conditions for Exploitation of Energy Resources: Analysis of Article 194(2) TFEU', European Energy and Environmental Law Review, vol. 23, no. 6

Hobe, S. 2015, 'Evolution of Principle on Permanent Sovereignty over Natural Resources' in Permanent Sovereignty over Natural Resources, eds. M. Bungenberg, S. Hobe, Springer, place of publication not stated Hofbauer, J. A. 2009, 'The Principle of Permanent Sovereignty over Natural Resources and Its Modern Implications', LL.M. thesis, University of Iceland

Jayasuriya, K. 1999, 'Globalization, Law, and the Transformation of Sovereignty: The Emergence of Global Regulatory Governance', Indiana Journal of Global Legal Studies, volume 6, no. 2, p. 44

Johnston, A., Marel, E. 2013, 'Ad lucem? Interpreting the New EU Energy Provision, and in particular meaning of Article 194(2) TFEU', European Energy and Environmental Law Review, vol. 22, no. 5 
Joint Declaration on the Application of the Euratom Treaty (No 4) adopted by the plenipotentiaries of the Treaty concerning the accession of the Kingdom of Norway, the Republic of Austria, the Republic of Finland and the Kingdom of Sweden to the European Union OJ C 241, 29/08/1994

Judgement C-490/10 European Parliament $v$ Council of the European Union [2012] ECLI: EU: C: 2012: 525

Judgment C-573/12 Ålands Vindkraft $A B$ v Energimyndigheten [2014] OJ C $292 / 4$

Judgement T-370/11 Republic of Poland v Commission [2013] OJ L 114/34

McEachern, W. A. 2006, Economics: A Contemporary Introduction, $7^{\text {th }}$ edn, Thomson South-Western, Mason

Nanda V. P., Pring, G. R. 2013, International Environmental Law and Policy for the 21st Century, $2^{\text {nd }}$ rev. edn, Martinus Nijhoff Publishers, Leiden

Pereira, R., Gough, O. 2013, 'Permanent Sovereignty over Natural Resources in the $21^{\text {st }}$ Century: Natural Resource Governance and the Right to Selfdetermination of Indigenous People under International Law', Melbourne Journal of International Law, volume 14, no. 2

Permanent Sovereignty over Natural Resources, UN General Assembly Res 1803 (XVII) (14 December 14 1962) 17 UN - GAOR Supp. No 17 UN Doc. $\mathrm{A} / 5217$

Pielow, J.-Ch., Lewendel, B. J. 2011, 'The EU Energy Policy after the Lisbon Treaty' in Financial Aspects in Energy: A European Perspective, eds. A. Dorsman and others, Springer, Heidelberg

Reinhard, H. 1980, Rechtsgleichheit und Selbstbestimmung der Völker in wirtschaftlicher Hinsicht - Die Praxis der Vereinten Nationen, Springer, Berlin 
Schrijver, N. 1997, Sovereignty over Natural Resources: Balancing Rights and Duties, Cambridge University Press, Cambridge

Schulenberg, S. 2009, Die Energiepolitik der Europäischen Union, Eine kompetenzrechtliche Untersuchung unter besonderer Berücksichtigung finaler Kompetenznormen, Nomos, Baden-Baden

Simm, M. 2012, 'The interface between Energy, Environment and Competition Rules of the European Union', XXV FIDE Congress, Tallinn, May/June 2012

Sveen, T. 2014, 'The Interaction between Article 192 and 194 TFEU: Renewable Energy Promotion with a Predominant Environmental Purpose' in EU Renewable Energy Law: Legal Challenges and New Perspectives, ed. T. Solvang, University of Oslo, Oslo

Talus, K. 2013, EU Energy Law and Policy: A Critical Account, Oxford University Press, Oxford

Texaco v Libyan Arab Republic, reprinted in 17 ILM (1978) 3-37

Vedder, H. 2010, 'The Treaty of Lisbon and European Environmental Law and Policy', Journal of Environmental Law, vol. 22, no. 2

Vooren, B. 2011, 'Legal and Institutional Obstacles to an EU External EU Energy Policy post-Lisbon: Managing the Vertical and Horizontal Axes. Available at: <http://ecpr.eu/filestore/paperproposal/9167c3ef-000b-43acb76a-2d29c9dfc867.pdf> accessed 5 April 2016

Vooren, B., Wessel, R. A. 2014, EU External Relations Law: Text, Cases and Materials, Cambridge University Press, Cambridge

Westaway, J., Simpson, J. 2011, 'The Disintegration of the Concept of Sovereignty and the Energy Sector in the Europe' in Financial Aspects in Energy: A European Perspective, ed. A. Dorsman and others, Springer, Heidelberg 